\title{
委託研究報告
}

\section{國立榮養研究所委託研究報告抄錄 II}

Reports for Researches entrusted by the National Institute of Nutrition. (Part 2)

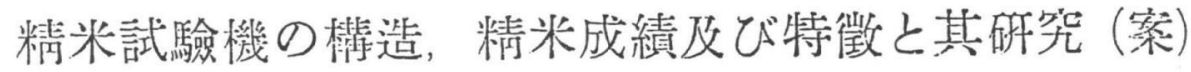

\begin{tabular}{|c|c|}
\hline & \\
\hline 京都大學㸚授 & 戶 \\
\hline
\end{tabular}

\section{1 精米試驗機の構造と精米原理}

現行及び在來の精米機による精米の原理は概ね杵四学機㑘化したるものに過ざずして米粒檿

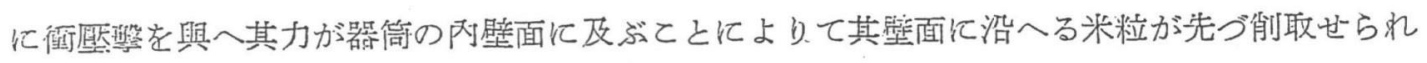

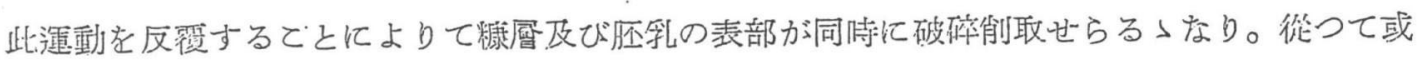

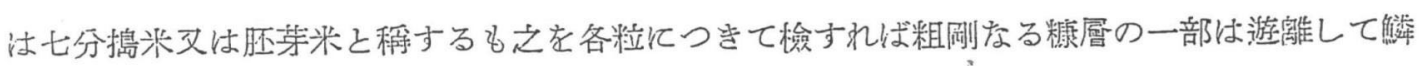

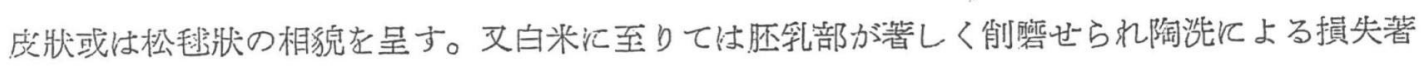
しを缺陷酷り。

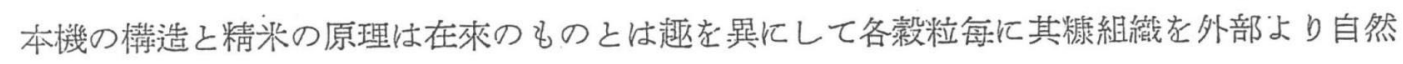

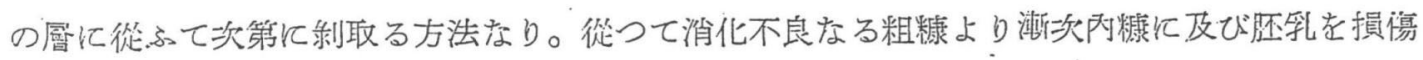
ぜざるを特顽とす。

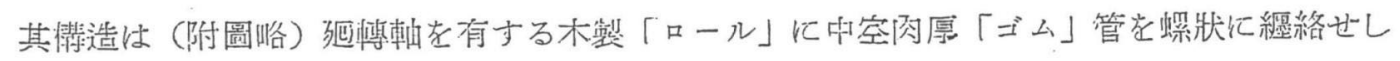

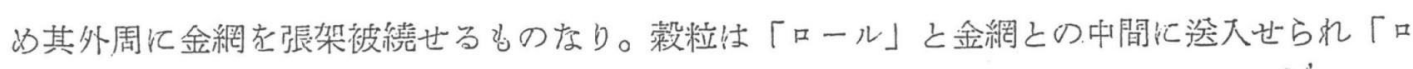

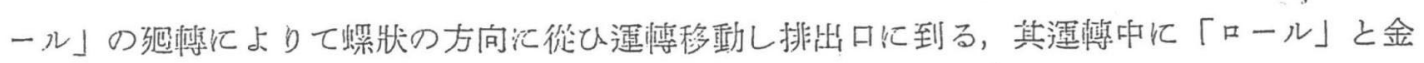

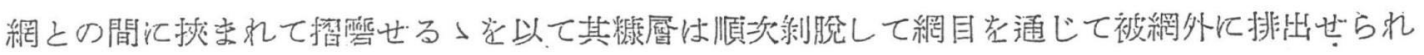
る。

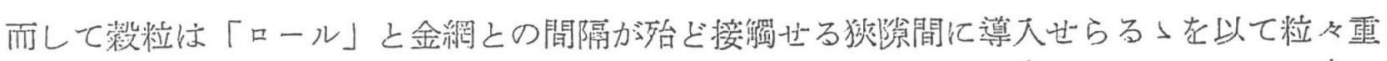

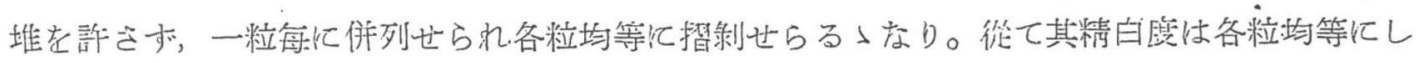

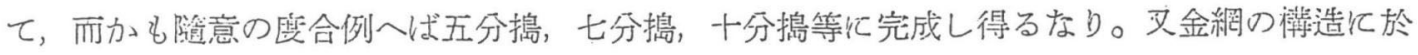

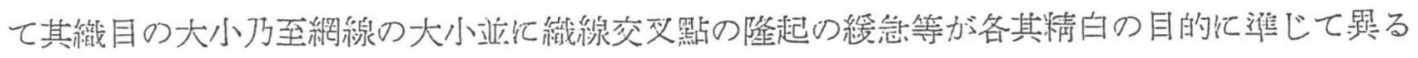

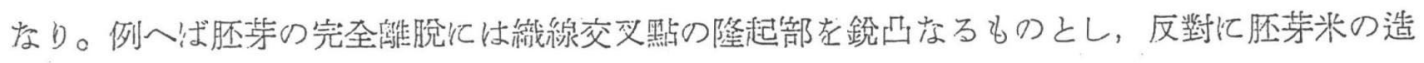




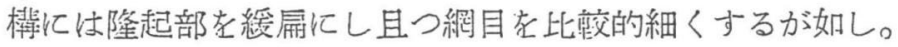

\section{2 䊦米試 驗 成 續}

\begin{tabular}{|c|c|c|}
\hline $\begin{array}{c}\text { 精米機種別 } \\
\text { 試驗項目 }\end{array}$ & 本試驗機汇よるもの & 淸水式精米機化よるもの \\
\hline 供試玄米量 & 59 正 720 瓦 (4 斗) & 60 的 ( 3 斗 8 我 7 合 1 勺) \\
\hline 所 要 動 力 & 1.60 馬力 & 1.65 馬力 \\
\hline 所 婹 時 間 & 45 分 & 45 分 \\
\hline 精白 (十分搗) 仕上量 & 55 正 659 瓦 & 55 䣶 400 瓦 \\
\hline 同碎 米 量 & なし & 190 瓦 \\
\hline 搗 精 缺 減 量 & 4 䏕 061 瓦 & 4 酥 600 瓦 \\
\hline 同‧上缺 滅 采 & 6 分 8 厘 & 7 分 6 厘 7 毛 \\
\hline 仕上白米 一 升 重 量 & 1 䏕 554 瓦 & 1 正 468 瓦 \\
\hline 摘 & 胚芽完全離脫仕精白 & $\begin{array}{l}\text { 㨶精後更に除精用研米機により仕上 } \\
\text { たるものなり泼芽殘存粒亩るを認さ }\end{array}$ \\
\hline
\end{tabular}

\section{3 本機による精米の特徵}

本㙨により精白せる白米は變筫せず從つて長期の眝藏に耐ゆ。此白米は陶洗するも毫も胚乳

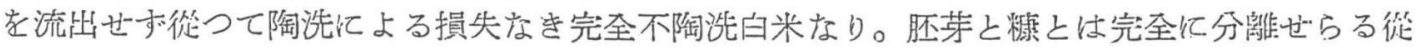
つて其利用も任意に行はる。精白は各粒均等に表噼より揩制せらるつが故に精白の程度は自由 に求めら㣗且つ所謂肧芽米孔自由作らる。

\section{4 本機の研究及び改良製作の要點}

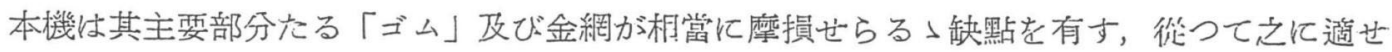
る「ゴム」の質の研究と鐵網の質と構造との研究を必呒とす。

\section{米の特殊搗精に關する㸴究 (抄錄)}

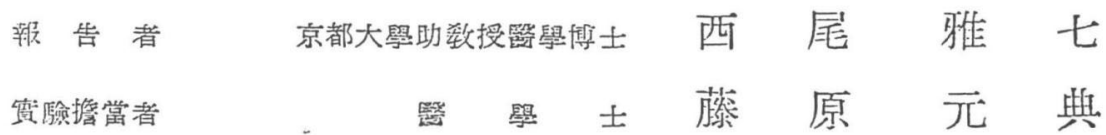

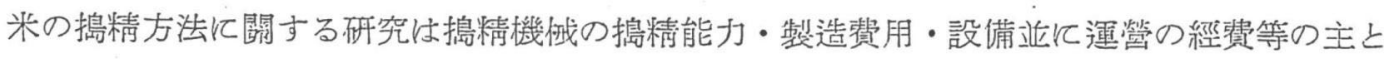

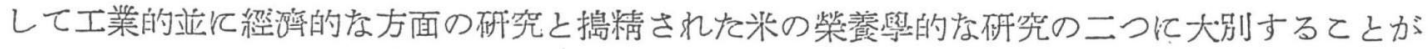
出來る。而して和食の如き食型式仿於ては米が重要な V. $\mathrm{B}_{1}$ 給源としての役割安演するもの

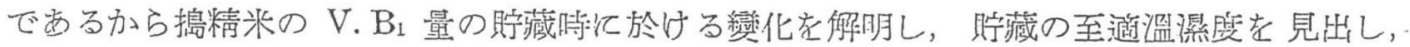

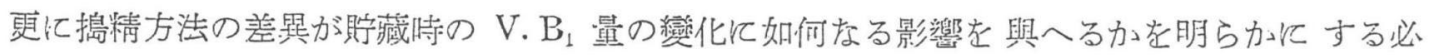

